\title{
Afyonkarahisar ve çevresinde diyalize giren kronik böbrek yetmezlikli hastalardaki deri bulguları
}

\section{Skin findings of dialysis patients with chronic renal failure in Afyonkarahisar and surrounding area}

Semih Güder, Șemsettin Karaca*, Mustafa Kulaç**, Șeref Yüksel***, Hüsna Güder****

Kartal Yavuz Selim Devlet Hastanesi, Deri ve Zührevi Hastalıklar Kliniği, İstanbul, Türkiye *Afyon Kocatepe Üniversitesi Tıp Fakültesi, Deri ve Zührevi Hastalıklar Anabilim Dalı ve

***Dahiliye Anabilim Dalı, Afyonkarahisar, Türkiye

**Namık Kemal Üniversitesi Tıp Fakültesi, Deri ve Zührevi Hastalıklar Anabilim Dalı, Tekirdağ, Türkiye ****Haydarpașa Numune Eğitim ve Araștırma Hastanesi, Deri ve Zührevi Hastalıklar Kliniği, İstanbul, Türkiye

\section{Özet}

Amaç: Hemodiyalize giren kronik böbrek yetmezlikli (KBY) hastalardaki deri değișikliklerinin sıklığını değerlendirmek.

Gereç ve Yöntem: On sekiz yaș üzerindeki randomize olarak seçilen 100 KBY'li hasta çalıșmaya alındı. Hastalar KBY'ye neden olan primer hastalıklar açısından 7 gruba, diyalize girme süreleri açısından da 3 yıl ve daha kısa ve 3 yıldan uzun olarak 2 gruba ayrıldı. Yaș, cinsiyet, hemodiyaliz süresi ve saptanan deri hastalıkları arasındaki ilișki t-testi ve ki-kare testi ile değerlendirildi. Bulgular ortalama değertstandart sapma șeklinde verildi ve $p<0,05$ ise anlamlı kabul edildi.

Bulgular: Hastaların hepsinde en az bir tane olmak üzere birçok deri bulgusu saptandı. En sık karșılașılan deri değișiklikleri kserozis (\%98), tırnak değișiklikleri (\%93), melanositik nevus (\%78), seboreik keratoz (\%54), pigmentasyon değișiklikleri (\%51), üremik pruritus (\%49), tinea pedis (\%34), aktinik keratoz (\%23), akrokordon (\%16), onikomikoz (\%17), lentigo (\%16) ve cherry anjiomdu (\%11). Tırnak bulgularından en sık dikey sırtlanma, yarım ve yarım tırnak, lunula yokluğu ve splinter hemoraji izlendi.

Sonuç: Çeșitli deri değișiklikleri kronik böbrek yetmezliğine sıklıkla eșlik etmektedir. Ayrıntılı bir dermatolojik muayene kronik böbrek yetmezlikli hastaların tanısında önemli bir rol oynayabilir. (Türkderm 2012; 46: 181-5)

Anahtar Kelimeler: Kronik böbrek yetmezliği, hemodiyaliz, deri bulguları

\section{Summary}

Background and Design: To evaluate the prevalence of skin changes in patient with chronic renal failure undergoing hemodialysis. Material and Methods: Over 18 year of age, 100 randomly selected patients were enrolled in the study. The patients were divided into 7 groups in terms of primary disease causing chronic renal failure, and were divided into two groups according to duration of hemodialysis ( $\leq 3$ years and $>3$ years). The association of diagnosed skin disorders with age, gender and duration of hemodialysis, were assessed using the t-test and chi-square test. Results are presented as mean \pm standard deviation and a $p$ value less than 0.05 was considered statistically significant.

Results: Many skin diseases, at least one, were found in all patients. The most common skin changes were xerosis (98\%), nail changes (93\%), melanocytic nevus (78\%), seborrheic keratosis (54\%), pigmentation changes (51\%), uremic pruritus (49\%), tinea pedis (34\%), actinic keratosis (23\%), skin tags (16\%), onychomycosis (17\%), lentigo (16\%), and cherry angioma (11\%). The most frequently observed nail changes were longitudinal ridging, half and half nails, absence of lunula and splinter hemorrhages.

Conclusion: Various skin changes are often accompanied by chronic renal failure. A detailed dermatological examination may play an important role in the diagnosis of chronic renal failure. (Turkderm 2012; 46: 181-5)

Key Words: Chronic renal failure, hemodialysis, skin findings 


\section{Giriş}

Kronik böbrek yetmezliği (KBY) multipl etyolojik faktörün rol oynadığı, nefron sayı ve fonksiyonlarında aşırı yıkımla sonuçlanan sıklıkla da son dönem böbrek yetmezliğine giden patofizyolojik bir süreçtir ${ }^{1}$. Kronik böbrek yetmezliğine birçok kutanöz bulgu eşlik eder ${ }^{2}$. Bu bulgular diyaliz tedavisine başlanmadan önce ya da tedavi sonrası dönemde ortaya çıkabilir ${ }^{3}$. Deri bulgularının gelişiminden vücuttan atılamayan toksik maddeler, hastaların kullandığı ilaçlar ve bozulan immünite sorumlu tutulmaktadır. Dolayısıyla deri bulgularının ortaya çıkma olasıığı böbrek yetmezliğinin süresi ve ciddiyetiyle doğru orantılıdır . Son dönem böbrek yetmezlikli (SDBY) hastalarda yarım ve yarım tırnak, pigment değişiklikleri, kseroz, akkiz iktiyoz gibi nonspesifik deri bulgularıyla beraber üremik pruritus, akkiz perforan dermatoz, kalsifilaksi, büllöz dermatozlar ve nefrojenik fibrozan dermopati gibi spesifik deri bulguları da karşımıza çıkabilir 5 . Kronik böbrek yetmezliğinde görülen deri bulguları iyi bir rehber olarak tanıya ulaşmada bazen ilk basamağı oluşturabilmekte ayrıca hastalık sırasında gelişen hipoalbüminemi veya hiperparatiroidi gibi bazı patolojileri de yansıtabilmektedir. Ayrıca hastaların morbiditesine katkıda bulunan bu deri bulgularının bazıları basit önlemlerle giderilebilmektedir. Bu amaçları göz önünde tutarak çalışmamızda Afyonkarahisar ve çevresinde diyalize giren kronik böbrek yetmezlikli hastalardaki deri bulgularının tipleri ve sıklığı araştırılmıştır.

\section{Gereç ve Yöntem}

Afyonkarahisar ve çevresinde hemodiyalize giren 18 yaş ve üzerinde olan kronik böbrek yetmezlikli 100 hasta çalışmaya alındı. Çalışma için etik kurul onayı alındıktan sonra çalışmaya alınacak hastalar çalışma hakkında bilgilendirilerek onamları alındı. Hastalardan kronik böbrek yetmezliği nedenleri, hemodiyaliz süresi, kullanmakta oldukları ilaçlar ve mevcut deri hastalıkları ile ilgili anamnez alındı. Hasta muayeneleri diyaliz seansı sırasında yapıldı. Muayene bulguları kayıt altına alındı. Dermatofit infeksiyonu varlığı nativ incelemesi ile doğrulandı ve şüpheli dermatolojik lezyonlardan deri biyopsileri alındı. Hastalar kronik böbrek yetmezliğine neden olan primer hastalıklar açısından 7 gruba, diyalize girme sürelerine göre ise 3 yıl ve daha kısa olanlar ve 3 yıldan uzun olanlar şeklinde iki gruba ayrılarak istatistiksel değerlendirmeler yapıldı. Laboratuvar değerlendirilmesi için hastalardan yeni kan örneği alınmadı, dosyalarında kayıtlı son bir hafta içindeki laboratuvar değerleri baz alındı. Hepatit serolojileri için son 6 ay içindeki mevcut değerler kaydedildi. Total protein değerleri 6-8 gr/dl, albümin (Alb) 3,5-5,5 gr/dl, kalsiyum (Ca) 8-5-10,2 mg/dl, fosfor (P) 6-7 mg/dl, parathormon (PTH) 100-150 pg/dl, demir (Fe)

\section{Tablo 1. Hastalarımızdaki KBY etyolojisi}

\begin{tabular}{|l|c|}
\hline Diyabetes mellitus & $\% 27$ \\
\hline Hipertansiyon & $\% 22$ \\
\hline Glomerulonefritler & $\% 15$ \\
\hline Ürolojik nedenler & $\% 7$ \\
\hline Diyabet + Hipertansiyon & $\% 6$ \\
\hline Diğer & $\% 6$ \\
\hline Etyoloji belli değil & $\% 17$ \\
\hline
\end{tabular}

kadınlar için 60-140 $\mathrm{mg} / \mathrm{dl}$, erkekler için 80-150 $\mu \mathrm{g} / \mathrm{dl}$, ferritin 15-300 $\mathrm{ng} / \mathrm{dl}$, hemoglobin (Hb) 12-15 gr/dl normal değerler olarak kabul edildi. Veriler bilgisayara kaydedilerek SPSS ver. 11,5 programı ile yaş ve cinsiyet ile saptanan hastalıklar arasındaki ilişki T testi kullanılarak, hemodiyaliz süresi ve saptanan deri hastalıkları arasındaki ilişki ki-kare testi kullanılarak değerlendirildi. Sonuçlar ortalama değerıstandart sapma (SD) şeklinde verildi. $p<0,05$ ise farklılıklar anlamlı olarak kabul edildi.

\section{Bulgular}

Çalışmaya 20-79 (ortalama 54,35) yaşları arasında 46'sı kadın (\%46), 54'ü erkek (\%54) 100 hasta alındı. Ortalama hemodiyaliz tedavi süresi 4,83 yıldı (1 ay-26 yıl). Hastalar haftada üç seans hemodiyaliz tedavisi almaktaydılar. Hastalara hemodiyaliz sırasında diyaliz solüsyonu olarak bikarbonatlı diyalizat ve filtre olarak polisülfon membran kullanılmaktaydı.

Hastaların primer hastalıklarına bakıldığında ise KBY'nin en sık nedeninin diyabetik nefropati olduğu (\%27), bunu hipertansiyon (\%22) ve glomerül hastalıklarının (\%15) takip ettiği görüldü (Tablo 1). Kronik böbrek yetmezliğine spesifik deri bulgularından olan üremik pruritus hastaların \%51'inde tespit edilirken nefrojen fibröz dermopati ve kalsiflaksi izlenmedi. Dört hastada klinik olarak akkiz perforan dermatoz tespit edildi. Bunlardan ikisi deri biyopsisi alınmasını istemedi, diğer ikisinden alınan biyopsi örneklerinden sadece biri perforan hastalıkla uyumlu geldi.

Nonspesifik deri bulgularından kserozun hastaların tamamına yakınında mevcuttu. Hastaların yarısından fazlasında pigmentasyon değişiklikleri, üçte birinde ise dermatoheliyozis görüldü. Hastaların 52'sinde saçlar klinik olarak ince ve zayıf olarak izlenirken 33'ünde androgenik alopesi (AGA) olduğu görüldü.

Hastaların tamamına yakınında tırnak değişiklikleri izlendi. Altı hasta dışında tüm hastalarda en az bir tane tırnak bulgusu izlendi. En sık dikey sırtlanma olmak üzere yarım ve yarım tırnak, lunula yokluğu, splinter hemoraji, Terry tırnak ve onikoşizi görüldü (Tablo 2).

Genel deri hastalıklarına bakıldığında 2 hastada vitiligo, 2 hastada kontakt dermatit, 2 hastada akne, 1 hastada psoriazis, 1 hastada ürtiker, 1 hastada pigmente purpurik dermatoz olduğu tespit edildi. Kandida, onikomikoz ve tinea pedis olmak üzere 39 hastada en az bir mikotik deri infeksiyonu izlendi. Folikülit ve deri apsesi olmak üzere 3 hastada bakteriyel deri hastalığı olduğu görüldü. Viral deri infeksiyonlarından verruka vulgaris 11 hastada izlenirken bir hastada herpes labiyalis izlendi.

\section{Tablo 2. Hastalarımızda görülen tırnak değişiklikleri}

\begin{tabular}{|l|c|l|c|}
\hline Dikey sırtlanma & $51(\% 51)$ & Sarı tırnak & $6(\% 6)$ \\
\hline Yarım ve yarım tırnak & $34(\% 34)$ & Lökonişi & $5(\% 5)$ \\
\hline Lunula yokluğu & $29(\% 29)$ & Muehrcke bantları & $2(\% 2)$ \\
\hline Splinter hemoraji & $26(\% 26)$ & Melanonişi & $2(\% 2)$ \\
\hline Terry tırnak & $16(\% 16)$ & Piterjium & $2(\% 2)$ \\
\hline Onikoşizi & $11(\% 11)$ & Koilonişi & $2(\% 2)$ \\
\hline Onikoliz & $8(\% 8)$ & Onikogrifoz & $5(\% 5)$ \\
\hline Beau çizgileri & $6(\% 6)$ & Onikomikoz & $17(\% 17)$ \\
\hline
\end{tabular}


Tablo 3. Hastalarımızın laboratuvar parametreleri

\begin{tabular}{|c|c|c|c|c|c|}
\hline Parametre & Referans değer & Hasta sayısı & Parametre & Referans değer & Hasta sayısı \\
\hline \multirow[t]{2}{*}{ Total Protein } & $<6 \mathrm{gr} / \mathrm{dl}$ & 2 & \multirow[t]{2}{*}{$\mathrm{Hb}$} & $<12 \mathrm{gr} / \mathrm{dl}$ & 70 \\
\hline & $>8 \mathrm{gr} / \mathrm{dl}$ & 6 & & $>17 \mathrm{gr} / \mathrm{dl}$ & 0 \\
\hline \multirow[t]{2}{*}{ Albümin } & $<3,5 \mathrm{gr} / \mathrm{dl}$ & 7 & \multirow[t]{2}{*}{$\mathrm{Fe}$} & $<80 \mu \mathrm{g} / \mathrm{dl}$ & 40 \\
\hline & $>5,5 \mathrm{gr} / \mathrm{dl}$ & 0 & & $>140 \mu \mathrm{g} / \mathrm{dl}$ & 4 \\
\hline \multirow[t]{2}{*}{$\mathrm{Ca}$} & $<8,5 \mathrm{mg} / \mathrm{dl}$ & 11 & \multirow[t]{2}{*}{ Ferritin } & $<15 \mathrm{ng} / \mathrm{dl}$ & 0 \\
\hline & $>10,2 \mathrm{mg} / \mathrm{dl}$ & 3 & & $>300 \mathrm{ng} / \mathrm{dl}$ & 86 \\
\hline \multirow[t]{2}{*}{$P$} & $<6 \mathrm{mg} / \mathrm{dl}$ & 58 & \multirow[t]{2}{*}{$\mathrm{HbsAg}$} & \multirow[t]{2}{*}{$(+)$} & \multirow[t]{2}{*}{5} \\
\hline & $>7$ mg/dl & 16 & & & \\
\hline \multirow[t]{2}{*}{ PTH } & $<100 \mathrm{pg} / \mathrm{dl}$ & 11 & \multirow[t]{2}{*}{ Anti HCV } & \multirow[t]{2}{*}{$(+)$} & \multirow[t]{2}{*}{16} \\
\hline & $>150 \mathrm{pg} / \mathrm{dl}$ & 66 & & & \\
\hline
\end{tabular}

Laboratuvar bulgusu olarak hastaların çoğunda hipofosfatemi $(5,4 \pm 1,7 \mathrm{mg} / \mathrm{dl})$, parathormon yüksekliği $(415,9 \pm 352,8 \mathrm{pg} / \mathrm{dl})$ ve anemi $(10,9 \pm 1,4 \mathrm{gr} / \mathrm{dl})$ izlendi. Ayrıca hastaların 5 'inde HBsAg pozitifliği, 16'sında anti HCV pozitifliği olduğu tespit edildi ( Tablo 3). Üremik pruritus ile cinsiyet, yaş, primer hastalık, hemodiyaliz süresi, kseroz, anemi, parathormon, kalsiyum ve fosfor değerleri arasında anlamlı ilişki saptanmadı. HBsAg pozitifliği ile üremik pruritus arasında anlamlı bir ilişki tespit edilmezken üremik pruritus ve anti HCV pozitifliği arasındaki ilişki anlamlıydı $(p<0,05)$.

Pigmentasyon değişiklikleri ve dermatoheliyozis ile yaş ve hemodiyaliz süresi arasında anlamlı ilişki tespit edilmedi. Tırnak değişiklikleri ile yaş, sigara ve primer hastalık arasında istatistiksel olarak anlamlı ilişki tespit edilmezken cinsiyet ile yarım ve yarım tırnak, splinter hemoraji ve Terry tırnak arasında istatistiksel olarak anlamlı ilişki tespit edildi (sırasıyla; $p=0,001, p=0,006, p=0,017$ ). Ayrıca hemodiyaliz süresi uzadıkça splinter hemoraji ve yarım ve yarım tırnak görülme sıklığı artmıştı $(p<0,05)$. Yarım ve yarım tırnak hipoalbüminemik hastalarda daha sık izlendi $(p<0,01)$. Lunula yokluğu ise parathormonu yüksek seyreden hastalarda daha sıktı $(p<0,05)$

\section{Tartışma}

Üremili hastalarda en çok görülen semptom pruritus olup prevalansı \%50-90 arasında değişmektedir6. Magnus ve arkadaşları diyaliz tedavisindeki gelişmelere bağlı olduğunu düşündükleri üremik pruritus prevalansında \%22'lere varan bir azalma bildirmişlerse de Zucker ve arkadaşları üremik pruritus prevelansını \%66 olarak rapor etmişlerdir7. Çalışmamızda hastaların \%49'unda üremik pruritus olduğu tespit edilirken bunların ancak \%16'sında şiddetli kaşıntı olduğunu gördük. Bu veriler göz önüne alındığında üremik pruritus prevalansında belirgin azalma olmadığı ama üremik pruritusun şiddetinde azalma olduğu söylenebilir.

Yapılan epidemiyolojik çalışmalarda üremik pruritus ile hastaların yaş, cinsiyet, primer hastalık ve diyaliz süresi arasında ilişki olmadığı bildirilmiştir6-8. Bizim çalışmamızda da üremik pruritus ile hastaların yaş, cinsiyet, primer hastalık ve diyaliz süresi arasındaki ilişki istatistiksel olarak anlamlı bulunmadı.
Kaşıntı bazı hastalarda subjektif bir bulgu olabilse de birçok hastada deride liken simpleks, prurigo nodülaris ve keratotik papüller şeklinde belirtiler meydana getirmektedir. Bozulmuş renal fonksiyonların çok çeşitli pruritojenik maddelerin birikimine bağlı pruritusa yol açabileceği öne sürülmektedir6. Güleç ve arkadaşlarının 177 hemodiyaliz hastasını inceledikleri bir çalışmada hastaların \%50'sinden fazlasında ekskoriyasyonlar, keratin tıkaçlı papüller ve postinflamatuvar hiperpigmentasyon şeklinde deri lezyonları bulunduğunu bildirmişlerdir 5 . Bizim çalışmamızda ise farklı olarak az sayıda hastada pruritusa bağlı deri değişiklikleri izlendi. Bu durum pruritusun şiddetindeki azalma ile ilişkili olabilir.

Kseroz hemodiyaliz hastalarının çoğunluğunda bulunmakta ve pruritusa katkıda bulunabilmektedir. Kserozun epidermiste vitamin A düzeylerinde artışa yol açarak sebase ve ter bezlerinde atrofi ve disotonomi yoluyla pruritusa katkıda bulunabileceği ileri sürülmektedir. Kseroz şiddetiyle pruritus arasındaki ilişkiyi deri yüzey hidrometresi kullanarak araştıran pek çok çalışmada deri hidrasyonuyla pruritus arasında ilişki gösterilememiştir. Akyhani ve arkadaşlarının yaptığı çalışmada pruritik ve nonpruritik hastalardaki kseroz prevalansı sırasıyla \%61,4 ve \%66 olarak bulunmuştur8. Biz hastalarımızın \%98'inde kseroz izledik, kseroz şiddeti ile pruritus arasındaki ilişki istatistiksel olarak anlamlı değildi.

Bazı araştırmacılar artmış serum fosfor ve kalsiyum düzeylerinin üremik pruritusa katkıda bulundukları öne sürmüştür. Derideki artmış divalan iyon konsantrasyonunun kalsiyum ve fosfor mikropresipitatlarının oluşumuna yol açarak kaşıntıya neden olduğu ileri sürülmektedir. Buna rağmen birçok çalışmada serum kalsiyum ve fosfor düzeyleriyle üremik pruritus arasında herhangi bir ilişki bulunamamıştır8. Çalışmamızda da hiperkalsemili ve hiperfosfatemili hastalarda üremik pruritus daha sık gibi görünse de bu ilişki istatiktiksel olarak anlamlı değildi. Hiperparatiroidinin de üremik pruritus patogenezinden sorumlu olabileceği düşünülmekte ve paratiroidektomi sonrasında kaşıntının kaybolması bunu desteklemektedir. Diğer tarafdan paratiroid hormonun üremik pruritusa neden olup olmadığı sorgulandığında PTH analoglarının intradermal injeksiyonu sonrasında kaşıntıda artış olmaması ve deri biyopsi örneklerinde immünhistokimyasal olarak PTH'nın negatif olması kaşıntı oluşmasında PTH'nın direk rolünün olmadığını 
desteklemektedir. Birçok çalışmada ise serum PTH seviyeleri ile kaşıntı varlığı arasında korelasyon bulunmamıştır9,10. Çalışmamızda da pruritus varlığı ile PTH seviyeleri arasındaki ilişki istatistiksel olarak anlamlı bulunmadı.

Bazı otörler demir eksikliği anemisinin renal kaşıntıya katkısının olabileceğini ileri sürmüşse de yapılan çalışmalarda üremik pruritus ile anemi arasında ilişki saptanmamıştı ${ }^{5}$. Çalışmamızda serum hemoglobin düzeyleri ile pruritus varlığı ve şiddeti arasındaki ilişki istatistiksel olarak anlamlı bulunmadı.

Hemodiyalize giren hastalarda HBV enfeksiyonu prevalansı son yıllarda \%11-12,2 olarak bildirilirken HCV enfeksiyonu prevalansı ise \%10,8-18 sıklığında bildirilmiştir11,12. Ayrıca hepatit $C$ enfeksiyonunun üremik pruritus ile ilişkisi olduğu bildirilmiştir ${ }^{13}$. Çalışmamızda üremik pruritusu olanların \%24,5'inde anti HCV pozitif iken pruritusu olmayanların \%7,8'inde anti HCV pozitifliği tespit edildi. Üremik pruritus ile anti HCV pozitifliği arasındaki ilişki istatistisel olarak anlamlı iken üremik pruritus ile HBsAg pozitifliği arasındaki ilişki ise istatistiksel olarak anlamlı değildi.

Üremili hastalarda pigmentasyon değişiklikleri sık karşılaşılan deri değişiklikleri arasındadır. Derinin tipik gri-sarı rengini veren deride ve subkutan dokuda depolanan ürokrom pigmentidir. Hastaların özellikle güneş gören bölgelerinde hiperpigmentasyon gelişmesi karakteristik bir bulgudur ve bu durumdan doku seviyesi artmış melanin stimüle edici hormon sorumlu tutulmaktadır ${ }^{5}$. Diyalize giren hastalarda pigmentasyon değişikliklerinin \%25-70 sıklıkta olduğu ve böbrek hastalığının süresi ile ilişkili olarak arttığı bildirilmektedir4. Bizde hastalarımızın \%35'inde sarı, \%26'sında kahverengi ve \%35'inde güneş gören alanlarda artmış hiperpigmentasyon saptadık. Pigmentasyon değişikliklerinin sıklığı ile yaş ve hemodiyaliz süresi arasında istatistiksel olarak anlamlı ilişki saptanmadı.

Kronik böbrek yetmezliğine spesifik deri bulgularından kalsiflaksi sıklığı \%1-4 olarak bildirilmektedir15. Kalsiflaksi etyolojisinde kalsiyum, fosfat ve paratiroid metabolizmasındaki değişiklikler sorumlu tutulmaktadır3. Nefrojen fibröz dermopati ise çok daha nadir olarak görülen spesifik deri bulgularındandır4,14. Hastalarımızın hiçbirinde kalsiflaksi ve nefrojen fibröz dermopati saptamadık. Son yıllarda kalsiyum, fosfat ve paratiroid hormon değişikliklerinin daha iyi takip ve tedavi edilmesinin kalsiflaksi görülme sıklığını azalttığı düşüncesindeyiz. Hastalarımızın $\% 2$ 'sinde vitiligo, \%2'sinde kontakt dermatit, \%2'sinde akne, \%1'inde psoriazis, \%1'inde ürtiker, \%1'inde pigmente purpurik dermatoz olduğu tespit edildi. Bu verilere dayanılarak hemodiyalize giren kronik böbrek yetmezlikli hastalarda genel deri hastalıklarının sıklığında bir artış olmadığı söylenebilir.

Kronik böbrek yetmezliğinin çeşitli tırnak patolojilerine sebep olduğu bilinmektedir. Çeşitli kaynaklarda hemodiyalize giren KBY'li hastalarda \%62-82 arasında değişen sıklıkta tırnak değişikliklerinin olduğu rapor edilmiştir16-20. Biz de hastaların \%93'ünde en az bir tırnak değişikliği olduğunu saptadık (Resim 1).

En sık karşılaşılan tırnak bozuklukları yarım ve yarım tırnak, 2 çalışmada ise lunula yokluğu olarak bildirilmiştir16-20. Bizim çalışmamızda ise farklı olarak en sık karşılaşılan tırnak değişikliği dikey sırtlanma olarak tespit edildi. Çalışmamızda \%51 oranında tespit edilen dikey sırtlanma diğer iki çalışmada \%4 ve \%9,9 gibi düşük oranlarda bildirilmiştir17,18. Dikey sırtlanma yaşın ilerlemesi ile bulunması beklenen tırnak değişiklikleri arasındadır21. Çalışmamızdaki hastalarda dikey sırtlanmanın sık bulunması hastaların çoğunun ileri yaşta olması ile açıklanabilir. Tırnak değişiklikleri ile yaş ve primer hastalık arasında anlamlı ilişki tespit edilmezken erkeklerde yarım ve yarım tırnak, splinter hemoraji ve Terry tırnak daha sık izlendi $(p<0,01)$. Ayrıca yarım ve yarım tırnak ve splinter hemoraji ile hemodiyaliz süresi arasında istatistiksel olarak anlamlı ilişki tespit edildi. Hemodiyaliz süresi 3 yıldan uzun olan hastalarda yarım ve yarım tırnak (\%45) ve splinter hemoraji (\%35) sıklığının artmış olduğu görüldü.

Hemodiyalize giren kronik böbrek yetmezlikli hastalarda yarım ve yarım tırnak sıklığı \%7,7-26 arasında bildirilmektedir16-20. Bizim çalışmamızda yarım ve yarım tırnak sıkığı \%34 olarak tespit edildi. Yarım ve yarım tırnak ile albümin düzeyleri arasında istatistiksel olarak anlamlı ilişki tespit edildi. Albümin düzeyi 3,5 gr/dl'nin altında olan hastalarda yarım ve yarım tırnak sıklığının artmış olduğu görüldü. Bu değişikliğin hipoalbüminemiye sekonder gelişen tırnak yatağı ödemine bağlı olabileceği düşünüldü.

Hemodiyalize giren kronik böbrek yetmezlikli hastalarda lunula yokluğu \%13-31,9 oranlarında bildirilmektedir ${ }^{17-19}$. Gelişiminde anemiyle beraber farkı metabolik değişimler rol oynayabilir ${ }^{18}$. Bizim çalışmamızda da benzer olarak \%29 oranında tespit edildi ve parathormon düzeyleri yüksek olan hastalarda daha sık izlendi $(p<0,05)$.

Kronik böbrek yetmezlikli hastalarda hücresel immünitenin bozulmasına bağlı çeşitli infeksiyonlara yatkınlık izlenmektedir. Tinea pedis (\%34), onikomikoz (\%17) ve kandida (\%5) olmak üzere 39 hastada en az bir mikotik deri infeksiyonu izlendi. Viral deri infeksiyonlarından papilloma virus infeksiyonu 11 hastada izlenirken bir hastada herpes labiyalis izlendi. Folikülit ve deri apsesi olmak üzere 3 hastada bakteriyel deri hastalığı olduğu görüldü. Sık görüldüğü bildirilen pitriyazis versikoloru ise hastalarımızın hiçbirinde izlemedik. Çalışmamız Afyon ili ve çevresinde diyalize giren 18 yaşından büyük 100 kronik böbrek yetmezlikli hasta arasında yapılmıştır. Deri değişiklikleri, kronik böbrek yetmezliğinde sık görülür. Deri değişikliklerinden kseroz, pruritus, yarım ve yarım tırnak ve pigmentasyon değişiklikleri gibi bulguların erken dönem böbrek yetmezliğinin habercisi olabileceği unutulmamalıdır. Kronik böbrek yetmezliğinde ortaya çıkabilen deri değişikliklerinin bilinmesi ile hastaların erken tanı ve tedavi almaları sağlanabilecek ve yaşam kalitelerinin yükseltilmesi mümkün olabilecektir.

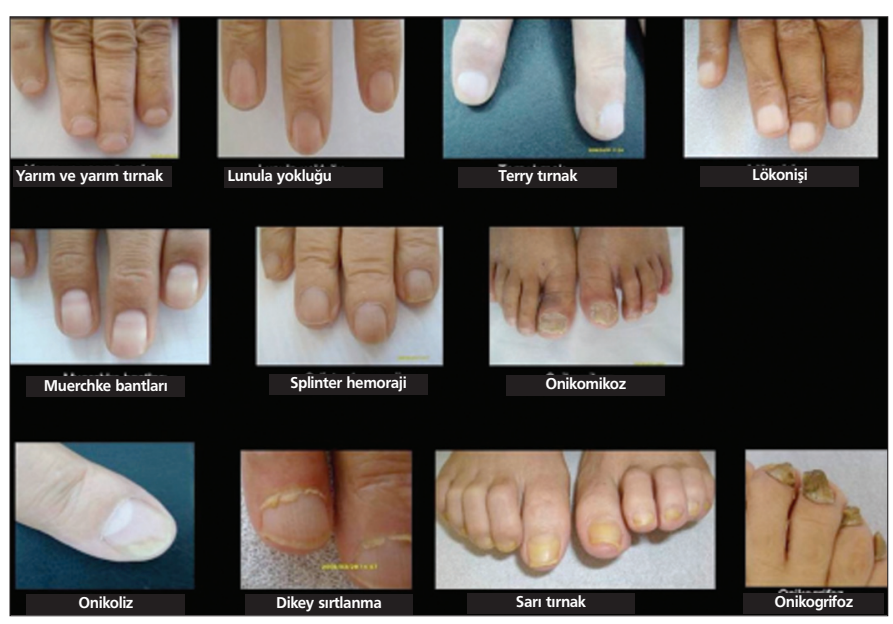

Resim 1. Hastalarımızda görülen bazı tırnak değişiklikleri 


\section{Kaynaklar}

1. Skorecki K, Grenn J: Chronic renal failure. Harrison's Principles of Internal Medicine. Ed. Dennis L. Kasper, Eugene Braunwald, Anthony Fauci, Stephen Hauser, Dan Longo, J. Larry Jameson. 16 th edition. San Francisco, McGraw-Hill Professional, 2004;2919-2934.

2. Nunley JR: Dermatologic manifestations of renal disease. eMed J 2002:550.

3. Robinson-Bostom L, DiGiovanna J: Cutaneous manifestation of end-stage renal disease. J Am Acad Dermatol 2000;43:975-86.

4. Abdelbaqi-Salhab M, Shalhub S, Morgan MB: A current review of the cutaneous manifestations of renal disease. Journal of Cutaneous Pathology 2003;30:527-38.

5. Güleç TO, Seçkin D, Erdemli JT, Güz G: Kronik böbrek yetmezliğinde deri bulguları. Türkiye Klinikleri Dermatoloji 1998;8:94-7.

6. Zucker I, Yosipovitch G, David M, Gafter U, Boner G: Prevalence and characterization of uremic pruritus in patient undergoing hemodialysis: uremic pruritus is stil a major problem for patients with end-stage renal disease. J Am Acad Dermatol 2003;49:842-6.

7. Mıstık S, Utaş S, Ferahbaş A, et al: An epidemiology study of patients with uremic pruritus. J Eur Acad Dermatol Venereol 2006;20:672-8.

8. Akhyani M, Ganji M, Samadi N, Khamesan B, Daneshpazhooh M: Pruritus in hemodialysis patients. BMC Dermatology 2005;5:7.

9. Narita I, Iguchi S, Omori K, Gejyo F: Uremic pruritus in chronic hemodialysis patients. J Nephrol 2008;21:161-5.

10. Nordal EJ, Os I: Uremic pruritus pathogenesis and treatment. Tidsskr Nor Laegeforen 2007;127:1201-3.
11. Taziki O, Espahbodi F: Prevalence of hepatitis $C$ virus infection hemodialysis patients. Saudi J Kidney Dis Transpl 2008;19:475-8.

12. Jain $P$, Nijhawan $S$ : Occult hepatitis $C$ virus infection is more common than hepatitis B infection in maintenance hemodialysis patients. World I Gastroenterol 2008;14:2288-9.

13. Chiu YL, Chen HY, Chuang YF, et al: Association of uraemic pruritus with inflammation and hepatitis infection in haemodialysis patients. Nephrol Dial Transplant 2008;23:3685-9.

14. Kurban M, Boueiz A, Kibbi A: Cutaneous manifestations of chronic kidney disease. Clinics in Dermatology 2008;26:255-64.

15. Hussein MR, Ali HO, Abdulwahed SR, Argoby Y, Tobeigei FH: Calciphylaxis cutis: a case report and review of literature. Exp Mol Pathol 2009;86:134-5.

16. Dyachenko P, Monselise A, Shustak A, Ziv M, Rozenman D: Nail disorders in patients with chronic renal failure and undergoing haemodilysis treatment. J Eur Acad Dermatol Venereol 2007;21:340-4.

17. Salem A, Al Mokadem S, Attwa E, et al: Nail changes in chronic renal failure patients under haemodialysis. J Eur Acad Dermatol Venereol 2008;22:1326-31. Epub 2008 Jun 5.

18. Saray $Y$, Seçkin $D$, Güleç $A$, Akgün $S$, Haberal $M$ : Nail disorders in hemodialysis patients and renal transplant recipients. Journal of the American Academy of Dermatology 2004;50:197-202.

19. Amatya B, Agrawal S, Dhali T, Sharma S, Pandey SS: Pattern of skin and nail changes in chronic renal failure in Nepal. Journal of Dermatology 2008;35:140-5.

20. Jamal A, Subramanian PT, Hussain KS: Nail changes in end-stage renal failure patients on hemodilysis. Saudi J Kidney Dis Transpl 2000;11:44-7.

21. Tüzün $Y$, Gürer MA, Serdaroğlu S, Oğuz O, Aksungur VL: Dermatoloji 3. baskı. Nobel tıp kitabevi, 2008; 1348. 